\title{
幼児の遊びの次元間の相互関係の検討
}

\author{
中 野 茂*
}

幼児の遊びに関する従来の研究では, “遊びの型”, “や りとりの型”，“遊び相手”の 3 つの次元のいずれか $1 つ$ のみから遊びへの接近がなされてきた。例えば, “遊び の型” の次元からの研究の事例としては, Bühler(1931) による『受容・象徴・運動・構成・感覚』の各カテゴリ 一を用いた分類, 並びに, その年齢傾向の研究, Piaget (1945)の『機能的・象徵的・ゲーム』遊びの発達的図式 の研究などの古典的成果が, まず, あげられよう。そし て, 最近の研究としては, それらの分類カテゴリーに基 づいて，それらの出現傾向の社会階層・文化差を調べた もの (Eifermann, 1979 ; Griffing, 1980), それら と認知的・社会的課題解決能力との関係性をみたもの

(Rubin \& Maioni, 1975) などが認められる。

一方, “遊び相手” の次元からの遊びの研究例として は, 1 つには, 遊び場面での人・物志向の個人差の安定 性を調べたもの（Emmerich，1964)，及び，それを認 知能力・社会性との関倸性を分析したもの (Jennings, 1975）があげられる。また，相手との年龄差による仲間 関係の相違 (Furman, Rake \& Hartup, 1979), 更に, 相手の性差によるやりとりの違いなどの研究がなされて いる。

3つ目の “やりとりの型” 次元に関する遊びの研究で は, Parten (1932) の集団遊びの発達的研究がよく知ら れている。そこに示された, 傍観のひとり遊びの平行遊 びら連合遊びら協同遊びの発達尺度は, 半世紀経た現在 でも有用なものとして認められている。しかし, 最近の いくつかの研究は, この尺度への次のような批判を提示 している。まず，彼女の対象児の年齢構成上の偏りと統 計処理の不適切さ (Bakeman \& Brownlee, 1980) で ある。第 2 に, ひとり遊びは年少幼児の未熟な遊び形態 ではなく, 年長児にみられる目標志向型の遊び(Moore, Everstone \& Brophy, 1974 ; Rubin, Maioni \& Hornung, 1976) であり，ひとり遊びと集団遊びとは相互 選択の関係にある（Roper \& Hinde, 1978 ; Smith, 1978）といら批判である。第 3 に, 平行遊びは発達の一

*北海道大学大学院教育学研究科
段階ではなく, 活動形態の移行途上を示す一過的な型で あるという (Bakeman \& Brownlee, 1980)。

このように, やりとり型の次元では, Parten 尺度の 見直しが，主要なテーマとなっている。

以上のように, 遊びの 3 つの次元における諸研究は, 遊びの心理学的研究に, それぞれの側面から一定の貢献 をしてきたといえよう。しかし, それらの諸研究が採用 してきた，単一の次元のみからの遊びへのアプローチと いら方法論は, 現実の子供達の遊びを考えた場合, 妥当 なものといえるだろらか。実際の子供達の遊びでは，そ れら 3 つの次元は『相手とあるやりとりの型で何かをし ている』というょうに，共起する 1 つのまとまりであり， 3 つの次元のそれぞれのカテゴリーが相互に結びつくこ とで 1 つの活動形態を構成していると考えられる。した

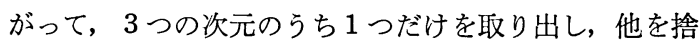
像するといら従来の方法論では, 例えば，平行遊びは相 手, 活動型の次元から独立な固有性を持つのか, それと も，他の次元との相互作用によって，質的に異なるいく つかの平行遊びが存在しらるのかといら問いに対する解 答は示しえないといえよう。

このように, 従来の研究では, 上のような次元間の相 互関倸の問題は考慮されないままとなっている。

しかし,このような状況の中で, 唯一, Rubin, Maioni \& Honung (1976), Rubin \& Watson (1978), Rubin (1982) らの研究は, この問題を直接, 対象としたもの といえる。彼らは, Piaget のカテゴリーと Parten の 尺度とを組合わせた尺度とを使って, やりとりの次元と 活動の型の次元との相互関係を調べている。

それらの研究から得られた知見によれば, Parten 尺 度上の一定のカテゴリーでも, 異なる Piaget カテゴリ 一と結びっくことで（例えば,『平行-機能』と『平行一 象徴』), それらの間での年齢差, 社会階層差, 関係する 社会的・認知的能力の違いを示すという。したがって, これらの知見に従えば, 遊びの次元を個々独立に扱うこ とは, このような次元間の相互作用によって生じる各力 テゴリーの質的相違を捨像し，単純化した幼児の活動の 
構造を，あたかも全体かのように把えてしまう危険性を 含んでいるように思われる。

また, 同様のことは, 上の 3 つの次元だけではなく, Krasnor \& Pepler（1980）にも述べられているょう他 の次元についてもいえる。つまり, 彼女らは, 従来の遊 びの研究は単純な “主効果”に基づいていると批判した うえで, Emmerich (1977) が示したような, 個体・場 面・発達変数の相互作用についての情報の不足と研究の 必要性を指摘している。したがって，上で述べた，いわ ば，遊びの “内的次元” の相互関係と同時に，それらと これらの，いわば，遊びの “外的次元” との相互関倸に ついても考慮していく必要があるといえよう。

本研究は, このような視点からのひとつの試みとし て，幼児の遊び場面の観察資料を，まず，遊び相手・や りとりの型・活動の型の 3 つの次元毎に分析し, 次に, それらの結果と，3つの次元を組合わせた尺度（以下， “3 次元組合わせパターン”と呼ぶ）上での結果との比 較検討を行ってみる。特に, その際, 他の次元を捨像し て得た単一の次元からの知見がどのような限界を帯びて いるのかを, ひとり遊び一集団遊びの自由選 択傾向

(Roper \& Hinde, 1978 ; Smith, 1978), つまり,ひ とり遊びと集団遊びとの関係性を中心に追求していく。

本研究での第 2 の目的は， 3 次元組合わせパターンに 基づく活動パターンの個人差の検討を行ってみることで ある。その際，個人差をクラスターとして把え，その間 の差異が発達差と独立な要因（偏好性など）によってい るのかどらかを検討してみる。

これらの検討を通して, 幼児の自由場面における遊び の構造を考察するとともに，可能な仮説を提起すること が，本研究の主たる目的である。

\section{方 法}

\section{1. 対象児}

5 歳児 13名（男児 7 名，女児 6 名，平均月龃 60.5)， 及び, 6 歳児12名（男児 6 名，女児 6 名，平均月齢70.7） で，合計25名の幼児。これらの幼児は，同じ幼稚園で， 同じ保育者によって，一緒の保育を受けていた。

\section{2. 観察方法}

自由時間中の各対象児の活動を10秒単位で10回(計100 秒) ずつ各週 1 回, 8 週連続して行った。従って, 対象 児は，延べ，13分20秒間観察され，80単位の資料が，各 児から得られた*。(この観察時間は, 他の研究と比べて 短期といえる。例えば, Parten (1932) は毎日 1 分ずっ

* 欠席者・途中での退園児が 1 人ずついた。これら の幼児では, 6 日 (60単位)の観察しかできなかった。
20日間, 合計20分間, Rubin ら (1976) は, 同じく, 30 日間, 計 30 分間の時間見本法による観察を各児に行っ ている。しかし，得られた各児当りの資料数では，本研 究の観察単位時間が短いために(10秒)，本研究の方が多 い。従ってそれらの研究結果との比較の際には, この点 を勘案することが必要といえる。)

3. 観察カテゴリー

(1) 遊び相手の次元

(1)物，(2)友人 (同輩) (3)大人 (教師)

(2)遊びの型の次元

(1)傍観（活動に参加せず，他者のすることを眺めてい る場合），(2もてあそび（対象物を反復的にいじり回し ている場合)，(3)構成（積木・紙などの部品を組合わせ て何かを作っている場合)，(4)機能的（体を使った活動 の5ち,ルールの認められないもの), (5)象徴(「ふり」, 「ごっこ」などの虚構による活動)，(6)教育的（描画・ 器楽演奏・折紙など, 教科関連の活動), (7)ゲーム(一定 のルールに基つくく活動)，88会話（進行中の活動から離 れたテーマについての話合い)。

(3)やりとりの型の次元

(1ひとり（他者の活動から独立な場合），(2)傍ら(他者 の傍らで同じことをしているが，やりとりの認められな い場合), (3一方的（相手への衝きかけが相手の応答を 伴わない場合)，(4)相互的（相手への㗢きかけに対応し た相手からの応答が認められる場合)。

観察の際には, 上の 3 次元から, 同時に, 1 つずつ, いずれかのカテゴリーが選ばれた。

\section{4. コーディングの信頼性}

ランダムに選んだ 8 名の対象児についての 2 人の観察 者の一致率は， $72 \sim 88 \%$ （平均 $84.3 \%$ ）だった。この比 率は, 四分相関の結果, 有意に高いことが確認された $\left(r_{t}=.57, \mathrm{CR}=3.17, \mathrm{P}<.01\right)$ 。

\section{結果*と考察}

\section{1. 単一次元の分析}

(1)年齢傾向：(1)遊び相手〜 5 歳児の $60.5 \%, 6$ 歳児の $65.8 \%$ が友人， 5 歳児の $31.6 \% ， 6$ 歳児の $26.3 \%$ が物， 残りが成人を相手としていた。従って，共に，それぞれ 6 割, 3 割, 1 割の順で, 同様の傾向にあり, 統計的違 いは認められなかった。相手の違いは，むしろ，年齢よ りも個人差の方が大きく，例えば，物を相手とした活動 の出現率のレンジは， 5 歳児で $17.4 \sim 51.5 \% ， 6$ 歳児で 14.9 44.5\%だった。

\footnotetext{
＊ 観察数の違いが対象児間にあったので, 結果は,
} 資料を比率化し，角変換後のものに基づいている。 
(1) Objects of children's activities

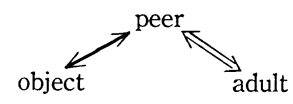

(2) Person interaction pattern

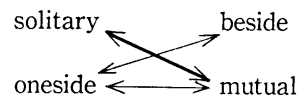

(3) Types of children's activities

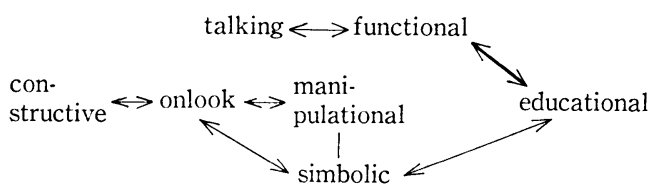

(NOTE: $\leftrightarrow$, negative correlation; -- , positive correlation; $\underset{\leftrightarrow}{\mathrm{p}}<.05 ; \doteqdot \mathrm{p},<.01 ; \leftrightarrows, \mathrm{p}<.001)$

FIG. 1 Correlation between categories within each activity dimension.

(2)遊びの型〜有意な年齢差は象徴遊びのみで認めら れ，6歳児の方が 5 歳児より多くの象徴遊びをしていた ことを示した $(\mathrm{U}=38, \mathrm{P}<.05)$ 。また，有意ではない が，顕著な違いが傍観と構成とで認められた(それぞれ， 5 歳児 $25.6 \% \cdot 6$ 歳巟 $19.3 \%$; 同前 $7.6 \%$ ・同後 $12 \%) 。$ その他のカテゴリーでは，何ら年齢的相違はなかった。

(3)りとりの型〜有意な年齡差は, ひとりと相互的や りとりで認められた。ひとりでいることは 6 歳児より 5 歳児に多く(各々，41.4\%vs : $54.0 \%, \mathrm{U}=37, \mathrm{P}<.05)$ ， 逆に, 相互的やりとりは, 5 歳児より 6 歳児に多かった (24.7\%vs, 33.3\%: U=38, $\mathrm{P}<.05)$ 。その他のカテ ゴリーでは年䶕的違いは認められなかった。

(2)次元内相関関係：それぞれの次元内のカテゴリー間 の一般的傾向を把えるために，その相関関係を調べてみ た。結果は, FIG.1 の(1)から(3)に示されている。

(1)遊び相手〜友人を相手とすることは, 物, 及び, 大人が相手の場合との間で，有意な負の相関を示した

(FIG. 1-(1) 参照)。これらの傾向 は, Jennings (1975) と同様で, 相手の志向性に友人と物, または, 大人とが あることが示唆される。

(2)やりとりの型〜 FIG.1-(2)には，3つの有意な対立 関係が示されている。それらのらち，相互的やりとりと ひとりとの対立は, Roper \& Hinde (1978), Smith （1978）らの“集団-ひとりオプション”の知見に反して いる。但し, 本研究と違って, 彼らは, 直接的行動を含 まない「ひとり」（何もしない，傍観）と「ひとり遊び」
とを区別している(つまり，「ひとり遊び」の方を「ひ とり」としている）点で定義上の違いがある。そこで, 相互的やりとりとひとり遊びとの関係性を調べてみたが 無関係にすぎなかった（r=-.14）。このことから，前 述したひとりと相互的との年龄傾向の違いを考えあわせ ると，ここでの資料は，むしろ，Parten (1932) の発達 傾向に類似したものといえる。

一方, 一方的と相互的やりとりとの対立関係も認めら

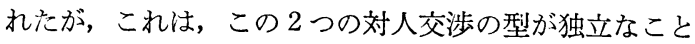
を示唆すると考えられる。更に, 一方的やりとりは, ひ とり以外の残りのカデ゙リーと, 相互的やりとりは, 傍 ら以外のカテゴリーと負の関係にある。つまり，一方的 やりとりは, 傍らと, 相互的やりとりは, ひとりと負の 関係にある。従って, 対人交涉の次元上で両者は独特な 位置にあるのではないかと考えられる。

(3遊びの型〜 FIG.1-(3)には，2つのタイプの負の関 係と 1 つの正の関係性が示されている。前者は, まず, 傍観と他のカテゴリーとの対立関係が，そうである。こ れは直接的働きかけが少なければ，自分ひとりでも，誰 かとでも，何かをするチャンスを得にくくなるので当然 の結果といえる。

もう1つのタイプの対立関係は, 教育的遊びと機能的 ・象徽的遊び, 及び, 会話と機能的遊びとの間で認めら れた。これは, 教育的遊び・会話とも机上, 又は, 定位 置で成されるのに対し, 他の 2 つは, 移動を伴う点で異 なるためと考えられる。換言すれば, 静的活動と動的活 動との対立関係といえよう。従って, 遊びの型の中に, このような志向性のあることが示唆される。

尚, 唯一の正の関係が認められたもてあそびと象徴遊 びとの関係は, 解积困難である。

\section{3 次元組合わせパターンの結果}

(1) 3 次元間の相互的関係性 : 3 つの遊びの次元の個々 のカテゴリーを「遊びの型一遊び相手一やりとりの型」の 順に組合わせたものをこの分析のための “組合わせパ ターン”とした。FIG. 2 には，観察されたこの組合わせ パターンのうち, 有意な相関の認められたものを正・負 に分けて示してある。以下では，それらについて，(1)月 齢との関係性, (2)次元間の相互的関係性, (3)特定のパタ ーンの偏好性の面から検討するとともに，単一次元の分 析結果との比較を行う。

(1)月齢との関係性〜年齡との正の関係性は，3つの組 合わせパターンが示した (FIG.2参照)。そのうちの 2 つ(「象徽・友人・相互」,「象徴・物・ひとり」) は, 象 徵遊びを含むパターンだった。この結果は遊びの型の次 元の単独の分析から得られた象徽遊びの年齡傾向と一致 


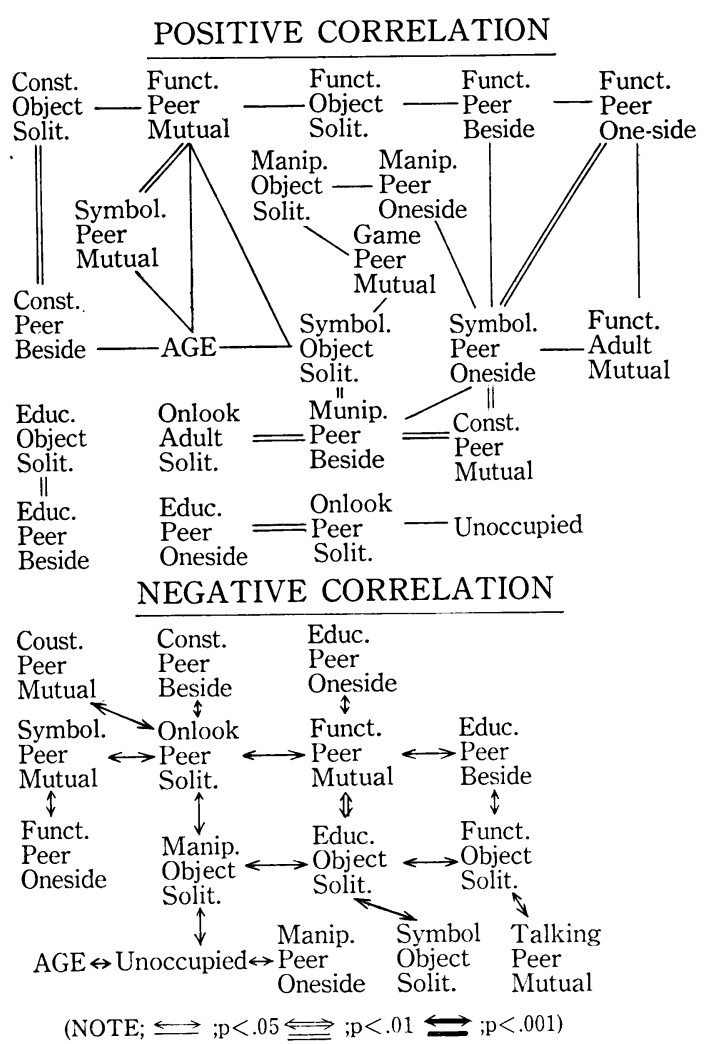

FIG. 2 Correlation between the combined categories with three activity dimensions.

している。しかし,この場合でも, 象徴遊びに関する観 察された組合わせパターンのうち,「象徽・友人・一方 的」は，月齢と正の相関が認められず，上述の単一次元 の結果にあてはまらない。

同様に,「象徴・物・ひとり」の結果は, 象徴遊びに ついては，上述のように，単一次元の結果に一致してい るが, ひとりについては, やりとりの型の次元単独の結 果から示された年齢傾向一年少児に多い一とは逆の傾向 となっている。従って，ひとり遊びでも象徴遊びを伴う 場合には, Parten(1932) とは異なり, Rubin ら (1976), Moore ら（1974）などと同様に，より年長児で認めら れることが，異なる観察単位に基づく，ここでの結果に ついてもいえる。

このように，ここでの結果は，3つの次元の組合わせ パターンによっては, 単一の次元の分析結果と一致した り，無関係だったり，反したりすることを示唆してい る。また，象徴とひとりについて言えば，遊びの型の次 元の方が，やりとりの型よりも強力な月齢による規定を 受けていると考えられる。

(2)次元間の相互的関係性〜前述のやりとりの型の次元
単独の分析による結果からは, Roper \& Hinde(1978), Smith（1978）らが示した“ひとり遊び-集団遊びの相 互選択傾向”とは逆に，ひとり遊びと相互的やりとりと の対立傾向が認められた。同じ傾向は, FIG. 2 の負の 相関の結果からも認められる。つまり,「機能的・友人 - 相互的」対「教育的・物・ひとり」, 及び，「会話・友 人・相互的」対「機能的・物・ひとり」の 2 組の相関関 係で，ひとり遊びと相互的やりとりとの対立を示してい る。この様に, これらの結果については, やりとりの型 の次元単独の分析から得られた傾向を支持しうる。

しかし，それらの相関の結果は，そのようなやりとり の型の次元の傾向の反映だけでなく, 同時に, 遊びの型 の次元の分析から得られた，機能的遊びと教育的遊び . 会話との対立関倸の反咉としても考えられる。従って, 本研究で得られたる次元組合わせパターンから, 個々の 次元単独の分析結果を見直してみると，上述の結果に関 する限りでは, やりとりの次元の結果も, 遊びの次元の 結果も, 個々の次元独立の傾向ではなく, 他の次元との 相互作用の結果ではないかと考えられる。

一方, FIG. 2 の正の相関結果についてみてみると，ひ とり遊び対相互的やりとりの対立という，やりとりの型 の次元の単独分析の結果とは逆の関係性が認められる。 つまり，「機能的・物・ひとり」と「機能的・友人・相 互的」「機能的・友人・相互的」と「象徵・物・ひと り」，及び，「構成・物・ひとり」,「ゲーム・友人・相互 的」と「象徵・物・ひとり」, 及び，「もてあそび・物・ ひとり」の 5 組の関係においてである。これらの結果か ら示唆されることとして，1つには，同じ遊びの型での 相関は，最初の機能的遊び同士でしか認められないこと である。もう 1 つには, その他の相関関係は, 遊びの型 が変わることで, ひとり遊びと相互的やりとりとの関係 性を示している点である。このことから，上述の相関関 係の組では, やりとりの型の次元単独分析結果に反し て, ひとり遊び-相互的やりとりの相互的選択傾向が, Roper \& Hinde (1978), Smith (1978) ら と同様に認 められるが，しかし，それらの結果も，やはり，やりと りの型の次元独立のものではなく，機能的遊びを除い て，遊びの型の次元との相互作用の結果であることがい える。つまり，子ども達はひとりでいる場合と相手とや りとりをしている場合では，遊びの型の切り換えをして いたと考えられる。従って，1つの推論として，ひとり 遊び-集団遊びの相互選択は，このような相手との交涉 様式に応じた遊びの型の切り換えスキルの水準の反映で はないかということが考えられる。

以上の結果が示すように, 個々の次元単独の傾向は, 
他の次元から独立ではなく, それとの相互作用の結果で あり, また, 相互作用の結果は, 同時に単一の次元の傾 向とは異なる “意味ある例外”も作り出していることが 示唆される。

(3)他の次元から独立なパターン〜これ迄述べてきた 3 次元間の相互関係の方で, 3 次元組合わせパターン間の 相関関係の結果は, 他の次元・カテゴリーから独立なパ

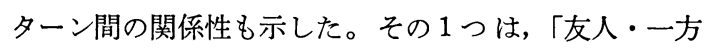
的」を含むパターン間の場合である。つまり,この $2 つ$ のカテゴリーを含むパターンは, むてあそび, 象徴遊 び, 機能的遊びなどの遊びの型の違いをこえて互いに正 の関係にあることが認められる。従って, 友人との一方 的やりとりは, 他のやりとりの型と異なり, 遊びの型の 次元とは独立な傾向にあったことが示唆される。

第 2 には, 機能的遊びの場合で, 既に, 次元間の相互 関係の箇所で述べたように, このカテゴリーは, 相手, やりとりの型の次元, 及び, 遊びの型の次元内の他のカ テゴリーとは独立なまとまりを示している。このこと は，機能的遊びが，他のカテゴリーに比べ，より多様な 場面で生じやすく，また，逆の見方をすれば，場面によ る切り換えが生じにくいといら特徴を持つことを示す結 果といえる。

以上の 2 つの場合は，様々な場面を通して保たれるも のであるが, 負の相関の結果をみると, それとは少し違 って, 特定のパターンの他に留まる場合が認められる。 つまり，「傍観・友人・ひとり」と「教育的・物・ひと り」の 2 つのパターンの場合で, 前者は, 他のほとんど のパターンと対立し, 後者は, 同様に, ひとりを含む他 のほとんどのパターンと対立を示している。従って, 友 人の活動の傍観が多い幼児は, 他の活動への切り換えの スキルで末熟であり，ひとりで教育的遊びをしていた幼 児は, ひとり遊びのレパートリーが限られていたと考え られる。

これらの他の次元, カテゴリーから独立なパターン, カテゴリーの存在は, 幼児の遊びの構造が, 前述したよ らな 3 次元間の相互関倸による可塑的部分と,このよう な固定的部分とを併存させて成り立っていることを示唆 するものと考えられる。

(4)因子分析の結果 3 次元組合わせパターン間の相互 関係が，どのようなまとまりを含んでいるかをみるため に, 因子分析を行った。その結果, TABLE 1 に示され ている様に，6つの組合わせパターンの集合，つまり， 潜在要因によるまとまりが見出された。これらのまとま りについて考察すると次のことが示唆される。まず， 1 つには, やりとりの次元についてみてみると, 個々の因
TABLE 1 Results of Factor Analysis Activity Patern Score Age Deff.

\begin{tabular}{|c|c|c|c|c|}
\hline & Manip., Peer, Beside & .20 & & \\
\hline \multirow{3}{*}{ Factor 1} & Manip., Peer, One-side & .18 & & \\
\hline & Symbolic, Object, Solit & .26 & & \\
\hline & Funct., Peer, Beside & .24 & & \\
\hline \multirow{3}{*}{ Factor 2} & Funct., Peer, One-side & .34 & & \\
\hline & Funct., Peer, Mutual & .22 & & \\
\hline & Funct., Object, Solit. & .29 & & \\
\hline \multirow{3}{*}{ Factor 3} & Const., Peer, Mutual & .35 & & \\
\hline & Const., Object, Solit. & .43 & $5 \mathrm{yr}$ & 1.44 \\
\hline & Symbolic, Peer, Mutual & .26 & $6 \mathrm{yr}$ & $6.56^{*}$ \\
\hline \multirow[t]{2}{*}{ Factor 4} & Onlook, Peer, Solit. & .37 & 5 yr & $29.04^{*}$ \\
\hline & Onlook, Adult, Solit. & .45 & $6 \mathrm{yr}$ & 15.54 \\
\hline \multirow{4}{*}{ Factor 5} & Const., Peer, Beside & .23 & & \\
\hline & Educ., Peer, Beside & .21 & & \\
\hline & Symbolic, Peer, Oneside & .49 & & \\
\hline & Educ, Object, Solit. & .14 & & \\
\hline \multirow[b]{2}{*}{ Factor 6} & Const., Peer, One-side & .44 & 5 yr & 2.43 \\
\hline & Educ., Peer, One-side & $\begin{array}{l}.47 \\
(* \mathrm{P}<\end{array}$ & $\begin{array}{r}6 \text { yr } \\
<.05)\end{array}$ & $4.47^{*}$ \\
\hline
\end{tabular}

子に含まれている組合わせパターンには，因子 4 を除き ひとりを含むものと，相互的，または，一方的やりとり を含むものとが，共に含まれていることである。しかも この 2 種のパターンは, 因子 2 を除いて, 異なる遊びの 型を伴っている。従って, 3 次元間の相互関係の結果で 記した, やりとりの次元と遊びの型の次元との相互作用 による，ひとり遊びと相互的やりとり，及び，一方的や りとりを含めた集団（対人）遊びの相互選択傾向が, こ こでの結果からも支持しらるといえる。

第 2 の因子分析の結果からの知見は, 各因子の年齢傾 向に関してである。TABLE 1 の右端に示されているよ 5 に, 有意な年齢差は, 因子 $3,4,6$ の 3 つ因子で認 められた。これらのらち, 傍観を含む組合わせパターン からなる因子 4 のみが，年少の 5 歳児に多くみられるも のであった。この傾向から, 遊びへの参加スキルに発達 差のあることが示唆されるとともに, 遊びの次元単独の 分析から得られた傾向との一致を示している。

一方, 2 つの 6 歳児に優位な因子の $5 ち$, 因子 3 は, 月齢と正の相関を示した「象徵・友人・相互的」と比 較的発達したひとり遊び (Rubin et al., 1978; Rubin 1981）と考えられる「構成・物・ひとり」を含んでいる ことが認められる。従って, より発達した遊びの水準を 表わす因子と考えられる。更に, このことは, ひとり遊 びと相互的やりとりの相互選択傾向が, Roper \& Hinde 
(1978)，Smith (1978) と同様に，より年長児で生じや すいことも示唆している。

もう1つの年長児により認められるパターンから成る 因子 6 は，上述の因子 3 と異なり，一方的やりとりを含 むパターンのまとまりである。しかも，一方的やりとり と相互的やりとりとは, FIG.1 亿示したように, 単一次 元の分析では，負の相関関倸にあるパターンである。ま た，因子 6 の「教育的・友人・一方的」は，「傍観・友 人・ひとり」と正の相関関係にあるのに対し，因子 3 の 2 つの相互的やりとりを含むパターンは，それと負の関 係にある。同様に，因子 6 の「教育的・友人・一方的」 は, 「機能的・友人・相互的」と負の関係にあり, 逆に, 因子 3 の「構成・物・ひとり」,「象徽・友人・相互的」 は正の関倸にある。従って，年齢差が認められたといっ ても，2つの因子は，異なる年齢傾向の側面か，年長児 の特定の集団の, つまり, 個人差の反映と考えられる。
第 3 の興味ある因子分析の結果は, 特定のカテゴリー を含むパターンからなる因子の存在である。つまり，因 子 2 は，機能的遊びを含むパターンからなり，因子 4 は，傍観を含むパターンからなり，因子 6 は，一方的や りとりを含むものからなっている。このことは,これら のカテゴリーが，他の次元のカテゴリーとは共通要因を 持たないこと，換言すれば，それらから独立しているこ とを示すものといえる。この傾向は, 既に， 3 次元間の 相互関倸の結果の中で, 他の次元から独立なパターンと して記したことと一致している。従って，そのような独 特なパターンの存在が，因子分析によっても支持される ことを,ここでの結果は示したといえる。

このような独特のパターンの存在は, 因子 $1,3,5$ の ように, 異なる次元間, カテゴリー間を超えて 1 つの因 子としての特徴を形成しているものともに, 他から独立 なパターンが併存することで遊びの構造が作られている

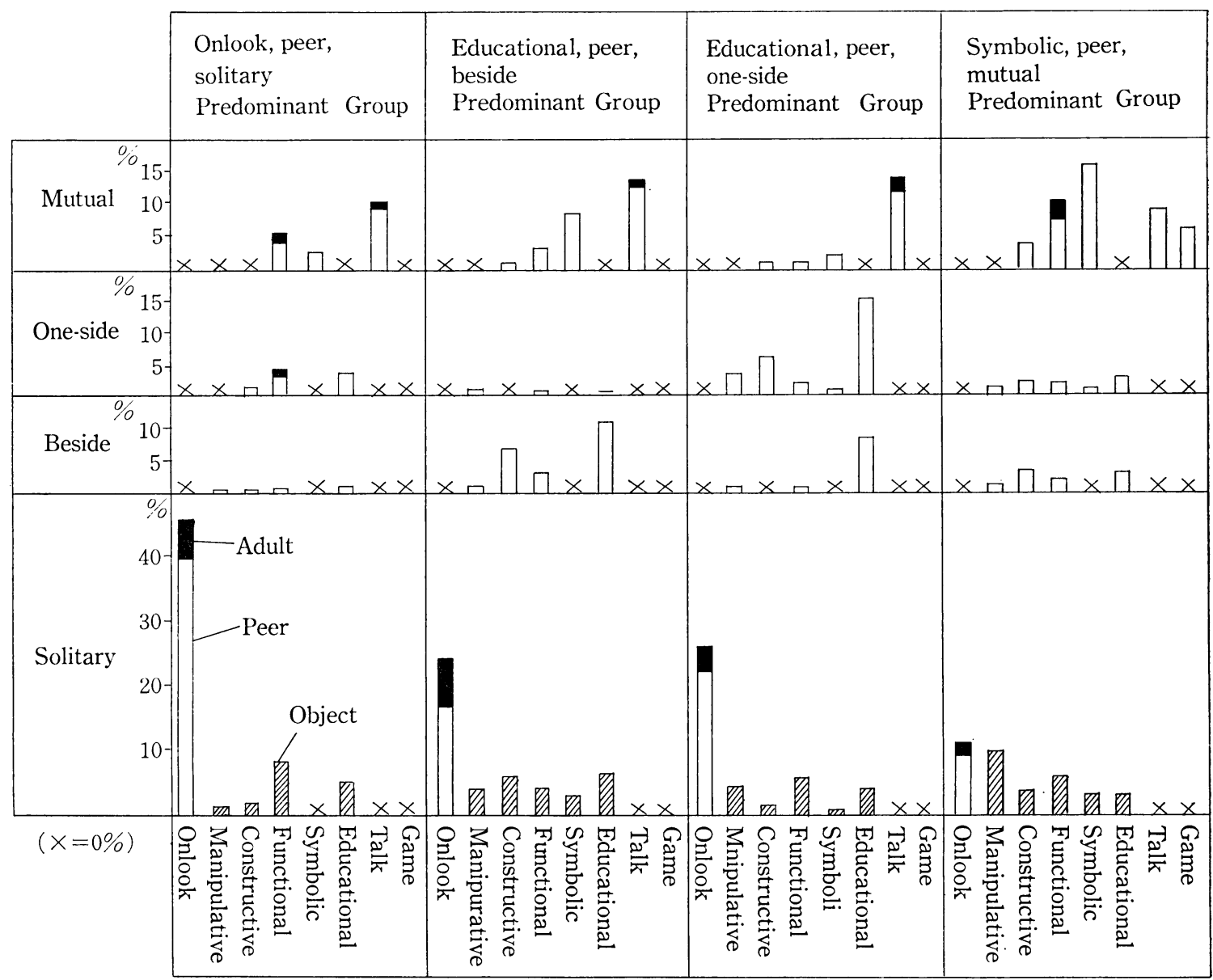

FIG. 3 Difference between the activity structures of four groups classified by the predominant combined category. 
か, または，特定の対象児が，それらのパターンへの偏 好性を示した結果ではないかと考えられる。

\section{3. 組合わせパターンの個人差}

これまで述べてきた組合わせパターンの結果が, 対象 児全員の平均的遊びの構造を示しているのか, それと も，個人差の反映なのかをクラスター分析によって検討 してみた。クラスター分析の結果は, 個人間の組合わせ パターンの出現傾向の類似度が急減する地点で, 4 つの 群に対象児を分類した。それらの 4 群について, 組合わ せパターンの出現傾向を調べたところ, FIG.3に示した 特徴が見出された。そこで，4群を, 次のように命名す ることにした。i）「傍観・友人・ひとり」優位群（以下， OPS 群と略記), 5 歳児 5 名 $\cdot 6$ 歳児 1 名 (以下, 同順) ii)「教育的・友人・傍ら」優位群(EPB群), 3 名・ 3 名; iii)「教育的・友人・方的」 (EPO群), 3 名・ 3 名; iv)「象徴・友人・相互的」優位群 (SPM群), 2 名, 7 名。

これら 4 群間の類似度関係は, FIG.4に示されている 通りである。

(1)各群の組合わせパターンの出現傾向の特徴

(1)「傍観・友人・ひとり」優位群 $($ OPS 群) 〜傍観の出 現率が 4 群中最高で (SPM 群とは $\chi^{2}=8.64, \mathrm{df}=3: \mathrm{CR}=$ $2.95, \mathrm{P}<.01$ で, 有意だった)年少児がその成員のほと んどだった。従って，ひとり場面での年齢傾向，因子分 析で見出された因子 4 の傾向は，この群の傾向を，主と して，反映したものと考えられる。

この群のもう 1 つの特徴は, 相互的やりとりの内容に 表わされている。FIG.3 に示されているように, この群 でも，比較的低い比率ではあるが，機能的遊び・会話に よって相互的やりとりを実現していたことが認められ る。更に, 教育的遊びによって, 一方的やりとりの形で も対人交涉の機会を得ていたことも認められる。このよ うに, この群は, 傍観が顕著ではあったが, その一方 で, 3 つ遊びの次元上のカテゴリーの組合わせによっ て，限られた程度ではあるが，それ以外の活動のパター ンも示していたといえる。但し, その際, 利用しえた遊 びの型は, 機能的・会話, 及び, 教育的という限られた 範囲のレパートリーである点は, 興味樑い結果といえよ 5 。

(2)「教育的・友人・傍ら」優位群 (EPB群) 〜この群 は, 傍らの出現率が， 4 群中, 最高で, OPS群, EPO群 とは有意差を示した $\left(\chi^{2}=11.7, \mathrm{df}=3, \mathrm{P}<.01 ; \mathrm{CR}=\right.$ $2.63,3.26$, ともに, $\mathrm{P}<.01)$ 。その際の遊びの型は, 教 育的遊びが主で, 次いで構成遊びだった。また，ひとり 場面でも, 同様に, 教育的, 構成の 2 つの遊びの型が主
だった。従って, この群の幼児は, 教育的, 構成遊びの ような目標達成型の遊び形態を好むのではないかと考え られる。この意味で, この群は偏好性を持っていたとい えよう。

しかし, 注目されることは, この群の相互的やりとり をみると,「象徽・友人・相互的」の出現率がSPM群に 次いで高いことである。このパターンは，既に述べたよ うに，年需的に高い水準で出現する傾向にあることを考 えると, この群の幼児は, ひとり, 傍らでの個人的, 目 標達成的活動志向の一方で, 高次の直接的対人交涉スキ ルも，限られた範囲ではあるが，備えていたと考えられ る。つまり，3 次元の相互関係の箇所で述べた, 場面に よる遊び形態の切り換えが, ある程度, 可能だったと推 論される。

(3)「教育的・友人・一方的」優位群 $(\mathrm{EPO}$ 群) ここの群 は, 一方的やりとりの出現率, 教育的遊びの出現率が他 の群より高く, 前者は, 他のすべての群より, 後者は, OPS 群と SPM 群より有意に高かった。（前者は， $\chi^{2}=22.91$, $\mathrm{df}=3, \mathrm{P}<.01$ :EPB 群, OPS群, SPM 群の順に, $\mathrm{CR}=$ 4. 26, $\mathrm{P}<.001 ; \mathrm{CR}=2.80, \quad \mathrm{P}<.05 ; \mathrm{CR}=2.50, \quad \mathrm{P}<$ .05 : 後者は $\chi^{2}=11.73, \mathrm{df}=3, \mathrm{P}<.01$ :OPS群, SPM群の 順に, $\mathrm{CP}=2.63,3.26$, ともに, $\mathrm{P}<.01)$ 。しかし, 逆 に, 機能的遊び, 象徴遊びの出現率は最低で, 有意な違 いを, 機能的遊びでは, OPS群SPM ・群との間 で, ( $\chi^{2}$ $=22.01, \mathrm{df}=3, \mathrm{P}<.01 ; \mathrm{CR}=3.08,4.07$, と も, $\mathrm{P}<$ $.01)$, 象徴遊びでは, SPM群との間で $\left(\chi^{2}=14.96, \mathrm{df}=\right.$ $3, \mathrm{P}<.01 ; \mathrm{CR}=3.06, \mathrm{P}<.01)$ を示した。更に，相互的 やりとりの比率も最低で, SPM群とは有意差を示した $\left(\chi^{2}=16.07, \mathrm{df}=3, \mathrm{P}<.01 ; \mathrm{CR}=3.20, \mathrm{P}<.01\right)$, 従っ て, この群は, やりとりの型の次元では, 一方的やりと りに偏し, 相互的やりとりが少なく, 遊びの型の次元で は, 教育的遊びが中心で, 機能的遊び・象徴的遊びはあ まりしないという特徵を持つといえる。

この特徴は, 単一の次元毎の分析から見出された。一 方的対相互的やりとり, 教育的対機能的遊びの対立関 係, また, 次元間の相互関係で認められた教育的遊び, 一方的やりとりへの偏好性の結果に一致している。ま た, 因子分析の結果では, 因子 6 と対応している。従っ て,これらの諸結果は, この群の個人差を主に, 反映し たものに思われる。

(4)「象徴・友人・相互的」優位群 $(\mathrm{SPM}$ 群) 〜この群の 特徵は, 既に, 他の群の結果の中で比較したように, 有 意に相互的やりとりが多く，その中での象徴遊びの比率 も高いことである。も51つには，ひとり場面での傍観 の比率が，他の群より著しく低いことである。逆に，物 


Group Amalg.
Onlook, peer, solit. Distance $\quad 5.00 \quad 10.00 \quad 15.00 \quad 20.00$
Predominant Group
Educ., peer, beside
Predominant Group
Symbolic, peer, mutual
Predominant Group
Educ., peer, one-side
$\quad$ Predominant Group

FIG. 4 Hierarchical Relationships Between Four Groups from Cluster Analysis.

に直接働きかける内容のひとり遊び（傍観以外の遊びの 型）の出現率，レパートリーは，4 群中最も高い。同様 の傾向は, 相互的やりとりでもいえ, 出現率の高まり は，レパートリーの挔がりを伴っていることが，そこで も認められる(FIG. 3 参照)。

このように, この群の特徴は, ひとり遊びの内容の充 実と相互的やりとりの高まりとして把えられる。つま り, 次元間の相互作用の結果として記した。ひとり相互 的やりとり相互選択傾向は，この群に最もあてはまるも のといえる。しかも, この群の成員が年長の 6 歳児中心 であることは，既に述べたように，このような場面によ る切り換え, または, 対人交渉の可塑性が, 発達的に達 成されていくことを示唆するものと考えられる。

尚, 因子分析の結果との対応では, 因子 3 の要因が, この群にあてはまると考えられる。

(2) 4 群の比較

上述の 4 つの群には, FIG. 4 に示されているように, $\mathrm{OPS} \cdot \mathrm{EPB} \cdot \mathrm{SPM} の 3$ 群間の類似性は高いが, EPO 群 のみ離れているという関係性のあることが認められた。 そこで, まず, 前者の 3 群間の類似関係について考察し たところ, 次のことが認められた。つまり,これらの群 は，いずれも, 程度の差こそあれ, ひとり場面と相互的や りとり場面とを遊び形態の中に含んでいることである。

それに対し，EPO群の場合は，相互的やりとりは 4 群 中最低の比率で, 内容も会話のみに限られている。その 代わりとして，前述したような一方的やりとり・教育的 遊びへの偏好性が著しい。このような傾向が上の 3 群と $\mathrm{EPO}$ 群との類似性の隔りを生んだと考えられる。従っ て, 3 次元の相互作用の結果の中で記した次元間の相互 関係による可塑的部分とは独立な固定的部分の存在が, 実は，個人差の反映であって，対象児全体の平均的傾向 ではないことを示しているといえる。

このような 4 群間の類似度関係の解釈が正しいとする と, 次のような仮説が示唆される。
その 1 つには, 上述したような共通の傾向に OPS • $\mathrm{EPB}$ - SPMの 3 群があるとすると, OPS群, EPB 群, SPM群の順に並べてみると，それらが，次のような同一 的変化の過程の各点に位置しているのではないかという ものである。つまり，ひとり場面では，傍観から対象物 への直接的働きかけへの変化, 対人場面では, 低い比率 から優位な相互的やりとりの出現率への増加への変化, 更に，それらの 2 つの変化の方向に伴う遊びの型のレパ 一トリーの拡大というような過程が仮説として考えられ る。しかも, それら 3 群の成員の年齢構成, 対応すると された因子の年齢傾向を考えあわせると, これらの解釈 が正しく, 微視的観察の範囲であるとの条件のもとに, それらの過程は発達的傾向を示しているのではないかと 仮定される。ところで，もしこのような発達的変化の過 程上に，それらの 3 群が位置していると仮定すると EPO 群についてはどのような解釈が可能なのだろうか。1つ の仮説としては,EPO群は,他の群とは異なる遊びの構造 をもつのではないかということがあげられる。つまり， 上述のように, $\mathrm{EPO}$ 群は, 直接的対人交涉を一方的やり とりで示している点で, OPS群, EPB群より発達したス キルを示しているといえるが，ひとり遊び・相互的やり とりの内容・レパートリーをみると, EPB群より限られ ているためである。

しかし，EPO群の成員には，年龄傾向が認められない が，対応する因子が，年長の 6 歳に優位な因子 6 である との解釈が正しければ, OPS群, 及び, EPB群よりも, 発達した水準の行動パターンとなる。従って, EPO群は, 何らかの要因によって,「教育的・友人・一方的」パタ ーンへの偏好性を生み, その結果, 遊びの構造は他の 3 群とは, 違った質的傾向を示したのではないかと仮定さ れる。

このようなEPO群の傾向と類似な結果は, 平行遊びに 関するSmith (1978)の結果でも認められる。そこでは, 継断的観察に基づいて，3，4 歳児の対人的遊びの発達的 変化は, 平行遊びが出現しても, それが優位な型となる ことはなく，ひとり遊び優位から集団遊び優位へと進む ことが示されている。もちろん, 本研究とは, 平行遊び と一方的やりとりの違い, 対象児の年齢の違い, 観察時 間の違いがあり，結果の比較はできないが，幼览の遊び のパターンの年齢的方向性が, Parten(1932)などが示し たような直線的なものではないのではないかということ を示唆する結果としては, 同様のものといえよう。

以上のように, ここでの 4 群の比較検討からは，ひと りから相互的やりとりの方向性と，それとは異なる方向 性の存在という複線的な発達傾向を予期した仮説が示唆 
される。これらの仮説の妥当性は, 今後, より幅広い年 齢範囲の幼児について，より長期的に追究していくこと によって，明らかとなっていくであろう。

\section{結論と今後の課題}

本研究の主たる目的は(1)従来用いられてきた単一の次 元からの接近法と, 本研究で用いた 3 次元間組合わせパ ターンによる方法との違い, 及び，後者の意義を示すこ と，(2)個人差の検討を行うこと, (3)以上の結果から, 遊 びの構造に関する仮説を提起することであった。第 1 の 目的に関しては, 単一次元からの知見は, 組合わせパタ ーンの一部のみの反映であること, そして, 次元間の相 互関係によって，単一次元の傾向とは異なる “意味あ る例外”の存在が明らかにされた。第 2 の目的について は，全体的傾向として考えられたものが，4つの個人差 に基づく群の反映が，少なくとも，それらを中心とした 傾向であることが示唆された。更に，この 4 つの個人差 の群の類似傾向から，2つの仮説が示唆された。つま り，1つには，ひとりから相互的やりとりへの変化の方 向性とそれに伴う，それぞれのレパートリーの拡がりで ある。もう1つには，そのような方向性とは独立な偏好 性に基ゔく傾向の存在である。

以上の検討を通じて明らかにされたように, 本研究で 用いた方法論は, 幼児の遊びの構造を把えるうえで有効 なものといえる。また，本研究で見出された上述の仮説 は, 幼児の遊びの発達的方向性を, より多岐的視点から 把え直すための手掛りになると考えられる。

しかし，それらの仮説が発達を意味するものであるた めには, 従来の研究と同様の巨視的・縦断的・広範な年 歯による発達的変化の把握が必要といえる。また，同時 に, 文脈的変化に沿った継時的分析によって，場面によ る行動パターンの切り換え, それとは独立な偏好性の追 究も, 今後の課題として重要に思われる。

\section{要 約}

従来の遊びの研究は， 3 つの遊びの次元一遊びの型， 相手, やりとりの型一の個々からしか, 遊びへの接近を 示してこなかった。本研究は, それら 3 つの次元を組合 わせパターンとして, 同時的に用いることで, 幼児の遊び の構造を記述し, そこから, 今後の研究の仮説を導き出 すことを目的として成された。この目的のため，25人の 幼稚園児の遊び場面を, 各人, 10秒毎, 10 回, 8 週続け て観察した。その結果, (1)単一の次元からの結果は, 3 次元の特定の組合わせの反映にすぎず，次元間の相互作 用による例外のあること, (2ひとりと相手のいる時とで,
遊びの型を切り換えていること，(3しかし，特定のパタ ーンへの偏好性も個人差として存在すること, 及び，(4) 個人差に, 2 つの方向性があることなどが, 見出された。

これらの結果から, 今後の仮説として, ひとりから相 互的やりとりとそれに伴らそれぞれのレパートリーの拡 がりの方向性, 及び，それとは異なる偏好性に基ゔく方 向性の存在の $2 つ か ゙$ 示された。また, 今後の課題とし て, これらの $2 つ の$ 仮説的傾向が, 発達的方向性を示し ているのかの吟味の必要性が提起された。

\section{引用文献}

Bakeman, R., \& Brownlee, J. R. 1980 The strategic use of parallel play:A sequential analysis. Child Development, 51, 873-878.

Bühler, C. 1928 Kindheit und Jugend. Hirzel, Leipzig.

Eifermann, R. R. 1971 Social play in childhood. In Herron, R. E., \& Sutton-Smith, B. (Eds.) Children's play. John Wiley \& Sons.

Emmerich, W. 1964 Continuity and stability in early development. Child Development, 35, 311332.

Emmerich, W. 1977 Evaluating alternative models of development:An illustrative study of preschool personal-social behaviors. Child Development, 48, 1401-1410.

Furman, W., Rake, D.F., \& Hartup, W. W. 1979 Rehabilitation of socially-withdrawn children through mixed age and same age socialization. Child Development, 50, 915-922.

Griffing, P. 1980 The relationship between socioeconomic status and sociodramatic play among black kindergarten children. Developmental Psychology, 16, 511-519.

Jennings, K. D. 1975 People versus object orientation, social behavior and intellectual abilities in preschool children. Developmental Psychology, 11, 511-519.

Jacklin, C. N., \& Maccoby, F. 1973 Social behavior at thirty-three months in same-sex dyads. Child Development, 49, 557-569.

Krasnor, L. R., \& Pepler, D. J. 1980 The study of children's play:Some suggested future directions. New Directions for Child Development, 9, 85-95.

Moore, N. V., Everstone, C. M., \& Brophy, J. E. 1974 
Solitary play:Some functional reconsiderations. Developmental Psychology, 10, 830-834.

Parten, B. M. 1932 Social Participation among preschool children. Journal of Abnormal and Social Psychology, 27, 243-269.

Piag et, J. 1962 Play, dreams and imitation in childhood. Norton.

Roper, R. \& Hind, R. A. 1978 Social behavior in a play group:Consistency and complexity. Child Development, 49, 570-579.

Rubin, K. H. 1982 Nonsocial play in preschoolers: Necessarily evil? Child Development, 53, 651-657. Rubin, K. H., \& Maioni, T. L. 1975 Play preference and its relationship to egocentrism, popularity and classification skill in preschoolers. MerrilPalmer Quarterly, 21, 171-179.

Rubin, K. H., Maioni, T. L., \& Hornung, M. 1976

Free play behaviors in middle- and lower-class preschoolers:Parten and Piaget revisited. Child Development, 47, 414-419.

Rubin, K. H.,\& Watson, K.S. 1978 Free play behaviors in preschool and kindergarten children. Child Development, 49, 534-536.

Smith, P. K. 1978 A longitudinal study of social participation in preschool children:Solitary and parallel play reexamined. Developmental Psycho$\log y, \quad 14,517-523$.

(1984年 4 月 23 日受稿)

\title{
ABSTRACT
}

\section{INTERRELATIONSHIPS BETWEEN PLAY DIMENSIONS IN PRESCHOOLERS}

\author{
by
}

\section{Shigeru Nakano}

Many studies on play in childhood have examined only one of the three main play dimensions:play partner,type of interaction, and type of play activities. However, it seems that child's play involves various combinations these dimensions.

In this study, interrelationships between dimensions, and individual differences in these dimensions were examined. Each of 25 preschool children was observed by two observers every ten sec. for a period of 100 seconds. Each play activity was coded in each of the above three dimensions by using a checklist. Each child was observed 8 times during an 8 week-period.
Results showed that the results based on a single dimension consisted of only one special combination of the dimensions. There were also "meaningful" exceptions. The combinatorial patterns of the dimensions were changeable depending on the situational demands.

However, it was also found that there were some preferences for a special type of the combinatorial pattern based on individual differences. From this result, a developmental model based on the situational changes in the combinatorial patterns and the individual differences was proposed. 